\title{
Curricular Objectives and the Challenge of the Digital School in Albania
}

\author{
Kozeta Noti \\ Pedagogy-Psychology Department \\ Social Science Faculty, Tirana University \\ E-mail: kozet.noti@gmail.com, Cel: 0692573795
}

\section{Doi:10.5901/jesr.2014.v4n1p463}

\begin{abstract}
The construction of the future school has been a priority for a decade of more than 55 states worldwide. The new way of doing school is now the subject and the centralization of restructuring the whole educational system. Technological innovations aren't outside school anymore but they are just inside of it. Access in informative resources through I/ Cloud Computing is now eminent. The main purpose of this research, in this view, is to examine and analyze either the Albanian educational system is nearer or further in facing the immediate challenge of digitalization in the educational process. This analysis is based in one of the most important actors and factors of the system that is the teacher. This article aims at giving an overview of the perception of teachers related to the formative needs and the relationship between formative needs and their attitude toward digital school. Statistical analyzes were performed using SPSS program, and more precisely, the relationship between these factors was revealed using general linear regression model.In conclusion, from the statistical analysis is revealed that there exists a positive relationship between perception of teachers related to the formative needs and their attitude toward digital school. Therefore adequate training on the operation and use of the technology in network would affect the new model of school, then the digital school.
\end{abstract}

Keywords: digital school, formative needs, teachers, training

\section{Introduction}

Technology is everywhere today, Albania is no exception! Despite the 'digital gaps' that appear so frequently in our schools, there is also real pressure from digital devices that students bring everyday into our classrooms (such as Smartphone of all types and shapes, I Pads, IPod, Mp3 players, etc.) All this "arsenal" of resources and information is extremely challenging for our teachers; not only for the quantity of information that it provides but also for the attractive way that introduces it. The teacher today, the Albanian one as well, is forced to accept the challenge: to be "updated" to get the information and attraction. This means to take advantage of the new technology to achieve one of the goals of the Curriculum which is the motivation to learn that goes simultaneously with learning to learn.

Countries joining late to "the epochal restructuring" of reference system in our case, the education system are "lucky" to arrive at the moment the process reaches its perfection in application. This is the case of Albania as well. Efforts and experiments conducted by schools worldwide have already outlined a defined and concrete way and best practices.

European Strategy for Education emphasizes that digital innovations in schools represent an excellent opportunity to transcend the traditional concept of "class", creating wide profitable space in acquiring knowledge, open to the world that enables "intelligent, sustainable and inclusive background" - three priorities of the European agenda in 2020 that will implement a modern concept of citizenship (European Agenda 2020).

Albania shares the same aspirations for education through the National Strategy by recognizing that new context of the daily changes in the national and international arena, this era of knowledge-based society, technology, globalization, competition etc, faces even Albania with a diverse population of students (diverse - because they've incorporated these digital devices now and the "Digital Natives" is a typical phenomenon after 2000) (Marc Prensky 2010, $\mathrm{pg}$ 27) This diverse classroom emphasizes the need to implement in the Education process methods and approaches compatible with their lifestyle. This diversity also dictates the need to treat students as "Partners in the education process" not as passive recipients of the knowledge. (Julio Meneses \& Josep Maria Momin'o 2011)

Our students, more than ever, are asking for "equal opportunity in education". (Albanian National Curriculum 2003) So, if students cannot attend school, the school could and should go to them. Today, through the digital school, the 
internet and intranet, the implementation of II Cloud Computing ${ }^{\star 1}$ (Ron Brown May 2013) it is more than possible!

This approach, besides helping in decreasing the cases of 'active' and 'passive' drop outs, will also help to bring into the Cl@ss 2.0*2 (Francesco Avvisati, Sara Hennessy,Robert B. Kozma and Stéphan Vincent-Lancrin, 2013) students that for health related disabilities or "isolation" aren't able to go to school physically. This approach would help children who abandon school temporarily for various economical and social problems.

The digital school is the best answer in implementing qualitative changes in the education process. Some of the necessary preconditions that fulfill successfully this operation include modern Curriculum, e-books, better infrastructure, professional training for teachers. (Long-term goals Albanian National Strategy 2009- 2014).

The Albanian National Curriculum has had three revisions and thousands of partial interventions since 2003 in order to precede or represent education needs in evolution. If objectives, goals and standards have been reflected and ratified in the Curriculum that have aimed IT in education until now, the digital school is nowadays the main subject and object of all the changes (school@ 2.0)3*(idem). This is a priority for the Albanian Government 2014-2020.

The materialization of curricular revisions in Alter-text is a visible, qualitative and main improvement because it has accompanied and deepened the most important process of the decentralization in the Albanian school, making it possible to conduct to the E-books - basic for the construction of the Digital School. E-books, posting of the textbooks online, ad hoc materials prepared from the teachers themselves, from the students with their teacher's help shared online and cloud (II Cloud Computing) are the nearest future in Albania, too. International experience in implementing school@, cl@ssroom, ide@ 2.0 and cp@*4 (Lipari D. 2007) will be a great and fast facilitation in implementing and then it'll define the success of the Digital School.

The Albanian policymakers of the entire political spectrum agreed in improving the school infrastructure and simultaneously the digital one. It confirms the fact that the digitalization process in education is concrete and prior.

We can mention the initiative of the Albanian Government to bring the internet to all Albanian Schools "Albania in the age of Internet". This project was mostly successful but could not totally reach its objective. Based on the data from the "National Strategy 2009-2013" we see the need for continuing effort on this matter. Until mid 2009, in 429 schools were established IT offices, 17 thousand computers, 2 thousand laptops and video projectors and approximately 2 thousand schools had internet access. There is a ratio of 32 students have 1 computer but concerning the objective it was 1 computer for 10 students until 2013.

One of the priorities of the Albanian Government for 2014-2020 is the equipment within 2014 of all freshmen (high school) with tablets and the teaching piloting. These efforts risk to be still "attempted" or unavoidably delayed if the teachers aren't sensitized about the "globalization" of the education process, the urgency digitalization of the Albanian school; and the necessity to involve definitely the teachers in redacting and selecting their right formative and training practices. In this way we'll have the reliability of the decrease in the digital gap, present not only in the students population but also in the teachers' one as well. Impressive but insufficient attempts were done through the engagement of the formative and training agencies in this direction: approximately 600 teachers in the country have benefited from "Pedagogical package in ICT" from the project "For Quality and Equality in Education" and 200 others have been trained and certified in ICT knowledge from the project "To Learn ICT in European dimension", implemented by Ceses (Progress Report of Albanian Government 2012).

It is a fact that this training package is only the first step toward the digital era, aiming to use the digital "language" in the education process but without deeply transforming education methodology that represents the only guarantee of the successful digital school. The analysis of the formative needs and the relationship between formative needs and their attitude toward digital school supports typically the statement mentioned above.

\footnotetext{
$1^{*}$ Cloud computing is a means of providing computer facilities via the Internet. It is that it is also a means of accessing those same computer facilities via the Internet from

different locations.Cloud computing has the potential to transform classrooms into paperless learning environments allowing for personalized, differentiated, anytime, collaborative learning for our students.

$2^{\star}$ is to pilot IT-rich learning environments that radically innovate on the traditional organization of teaching and learning.

$3^{*}$ scale up the digital school model: school access to broadband; cloud resources for teaching and learning; transforming learning environments; digital contents and e-books; teacher training through blended e-learning; interactive whiteboards; e-participation

$4^{*}$ consists of a set of people who are motivated to improve organizational outcomes, are the most functional on the one hand to promote the exchange between those who hold the knowledge, and the other to generate new knowledge
} 


\section{Methodology}

\subsection{Procedure and sample}

This study has been carried out through a quantitative and a qualitative research model. In this paper are presented only the data of the quantitative research. Withdrawal of the sample from the population is made with sample stage method. Initially, by means of these methods were selected four institutions in the country that offer trainings and then is selected the sample from the group of teachers trained by these institutions. First of all, the population that served for this sample is made of trained teachers by state and private institutions (approved by the Ministry of Education \& Science) that offer trainings for teachers in the first steps of their career or in advanced career. The institutions that were chosen were: The Institution of Curriculum \& Career; Regional Education Directory - Tirane, Korce, Vlore, Shkoder; Ceses; ISETT; that during 2010-2013 have certified 600 teachers of pre-university system in IT skills. In the whole country there are actually serving just 30.000 teachers and is also covered a sample of 400 participants from this population (Cohen, Manion \& Morrison, 1970, p 94).

As mentioned above, the stage probability sample is used to select the sample from this population. It involves selecting the sample in stages; that is, taking sample from sample. In other words, with the stage selection sample we select firstly a number of training agencies at random. Then within the selected training agencies, we randomly select a number of teachers trained during certain years (2010-2013). Finally, we select a number of teachers who have finished the training and have been certified. By means of this method is selected even the sample that represents the population features. Out of 400 teachers of the sample, just 130 are men and the other 270 are women, or $32.5 \%$ are men and 67.5 $\%$ are women. The largest number of participants, i.e., $73 \%$ is between $35-60$ years, followed by the $23-30$ years old, which comprise $17 \%$. Then comes the age group up to $30-35$ years with 6\%, and in the end is the age group 60-66 years with $3.8 \%$. Out of 400 participants in the study, $59 \%$ of them make up the group of the teachers working in the district of Tirana, i.e., the largest one. Some $41 \%$ form the group of other districts such as Korca, Shkodra and Vlora.

The educational level of the participants in the study varies from $33 \%$ who have got a University Degree in Natural Sciences to $55 \%$ who have got a University Degree in Social Sciences and just $12 \%$ of them are graduated in Information Technology. Only $0.5 \%$ of the teachers who have been attending trainings in learning computer skills in the teaching process have declared that these training courses haven't been useful in improving their performance in schools as they are in favour of traditional methods. Out of 400 participants, 150 or $37.5 \%$ have replied that have difficulties in implementation of the new models through digitalization, 242 teachers or $60.5 \%$ have answered that the training has been fully useful to change the way of teaching and only 8 teachers or $2 \%$ have replied that the training offered has changed their views and model of teaching. They totally use digital ways in their classroom.

\subsection{Instrument and its reliability}

The instrument used for gathering the data is a questioner made of some rubrics. The questionnaire is conducted by 400 respondents who in 15-20 minutes completed it. Initially participants were informed about the purpose of the study and clarified that the survey data will be used only for academic purposes. Given that the necessity of the professional training offered to teachers in IT to make them come closer to the digital school which is the only focus of this article, only the elements of the questionnaire will be represented. Two subscales are designed to measure the perception of teachers related to the formative needs and their attitude toward learning. Those are arranged in a scalar form, where teachers should circle the answer from strongly disagree to strongly agree, according to their level of agreement. Thus, item such as, their experiences, concerns, and didactic tools in their disposal are used to develop course content. Digitalization helps and encourages teachers to better understand the class population, to develop them digitally, and to approach II Claud Computing, so that can see it as the future of the digital school etc, are designed to measure teachers positive attitude toward digitalization in the classroom in proportion to their formative needs. Item such as, how much the teacher is helped by digital subsidy to be nearer the effective needs of the students, how much are teacher sensitised that the future of the school is digitalization of the process teaching/learning, so II Claud Computing, how further do teachers think of the future of Claud Computing, how much is it positive for them the sensitization of II Claud Computer through their training process in IT. Should the design of the formation be changed in order to be nearer to the world of II Claud Computing. All of these are designed to measure the perception of teachers for active usage of digital tools in teaching/learning and digital school. From the score calculations, for a three item scale, using a response scale from 1 to 5 , the minimum value would be 3 and the maximum value would be 15 . A mean score of 11.2 or higher indicates high 
level of positive attitude toward digitalization - II Claud Computing. A mean score between 7.1 and 11.1 indicate a mild level of positive attitude toward II Cloud Computing. A mean score below 7 indicates low level of positive attitude toward II Claud Computing. Furthermore, Cronbach's alfa was run in order to assess internal consistency and reliability for each of the two scales used to collect data. This scale, has a good internal consistency, with a Cronbach's alpha coefficient reported 81 .

For the perceptions of teachers regarding active learning environment through II Claud Computing scale, given a response for each item, the lowest possible mean score is 4 and the highest possible mean score is 20 . A mean score of 14.7 or higher indicates high level of perceptions of teachers regarding active new models of learning environment. A mean score between 9.4 and 14.6 indicates a mild level of perceptions of teachers regarding active new models of learning environment. A mean score below 9.3 indicates low level of perceptions of teachers regarding active new models of learning environment. This scale, has acceptable internal consistency, with a Cronbach's alpha coefficient reported .72

\section{Data analysis}

The data gathered from the survey was transported into the computer statistical package SPPS. Prior to reviewing the data, assumptions for the statistical analyses were assessed. The data have been examined for normality, as well as for missing data. A tow -tailed alpha level of .05 was set and used for all statistical tests.

Linear regression statistical analysis was conduct to assess whether the relationship between formative needs and their attitude toward digital school. The following table provides a summary of variables and the analytic procedures related to the paper question.

Table 1. Paper question, variables, and analytic procedures

\begin{tabular}{|l|l|l|}
\hline \multicolumn{1}{|c|}{ Paper Question } & \multicolumn{1}{|c|}{ Variables } & SPSS Procedures \\
\hline $\begin{array}{l}\text { What is the relationship between } \\
\text { formative needs and their attitude } \\
\text { toward digital school? }\end{array}$ & $\begin{array}{l}\text {-Positive attitude toward the need for training in the field to } \\
\text { lead to the digital school. } \\
\text { - Positive perceptions of teachers regarding digital school }\end{array}$ & Linear Regression \\
\hline
\end{tabular}

\subsection{Sources of error}

The way this research was carried out intended to minimize non real results. However, like most of the studies made in the field of the education and training, even this one is self-report based. As a result, the findings depend even on the teachers' acquisition of the questions in the survey as well as on the degree of sincerity they have completed the instrument with.

\subsection{Research ethics}

During the implementation of this study, all the stages of research ethics have been followed. It has firstly been taken the permission of the respective structures in charge where the instrument was conducted. Subsequently, a sensitization of the research and its goal was done to the participants before they filled the instrument. They were guaranteed anonymity and asked whether they wanted to participate voluntarily in the study. Furthermore, participants who did not want to be part of the study did not meet the instrument.

\section{Results and Discussion}

Table 2, Illustrate the mean scores and standard deviation regarding the positive attitude toward the need for training in the field through digital school ( $M=7.49, S D=3.1$ ) and their positive perception regarding digital school environment ( $M$ $=9.78, \mathrm{SD}=2.9$ ).

Table 2. Mean scores and SD for two variables.

Descriptive statistics

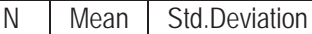




\begin{tabular}{|l|l|l|l|}
-Positive attitude toward the need for training in the field to lead to the digital school. & 386 & 7.49 & 3.10 \\
\hline Positive perceptions of teachers regarding digital school & 375 & 9.78 & 2.90 \\
\hline Valid N (listwise) & 366 & & \\
\hline
\end{tabular}

As we can see, from the data the mean scores of positive attitude toward the need for training in the field to lead to the digital school is 7.49 and this indicates a mild level of positive attitude toward new models of learning for them. The same situation is for the perception of teachers regarding digital school, where the mean score is 9.78 that indicates again a mild level of this perception for this variable.

To address the paper question, linear regression statistical analyses was conducted. This question has explored the fact if there exists or not a relationship between formative needs

and their attitude toward digital school? Table 3, indicates that $50.7 \%$ of the variance in the positive attitude toward the need for training in the field to lead to the digital school can be predicted from the independent variable that in this case, is perceptions of teachers regarding digital school.

Table 3. The variance of positive attitude toward digital school

Model Summary
\begin{tabular}{|c|c|c|c|c|}
\hline Model & R & R Square & Adjusted R Square & Std. Error of Estimate \\
\hline 1 & $.713^{3}$ & .509 & .507 & 2.18 \\
\hline
\end{tabular}

a. Predictors: (Constant). Positive perceptions of teachers regarding digital school

b. Dependent Variable: Positive attitude toward the need for training in the field to lead to the digital school.

The ANOVA table shows, that the overall model revealed to be statistically significant, $F(1,364)=376.666, p=.000$, adjusted $R^{2}=.507$.

Table 4. The significance for the linear regression model.

\begin{tabular}{|c|c|c|c|c|c|c|}
\hline \multicolumn{7}{|c|}{ ANOVA } \\
\hline & Model & Sum of Squares & Df & Mean Square & $\mathrm{F}$ & Sig. \\
\hline \multirow{3}{*}{1} & Regression & 1787.002 & 1 & 1787.002 & 376.666 & $0.003^{3}$ \\
\hline & Residual & 1726.913 & 364 & 4.744 & & \\
\hline & Total & 3513.915 & 365 & & & \\
\hline
\end{tabular}

a. Predictors: (Constant). Positive perceptions of teachers regarding digital school

b. Dependent Variable: Positive attitude toward the need for training in the field to lead to the digital school

An observation of individual predictor in Table 5 , indicates that perception of teachers positive perceptions of teachers regarding digital school $(B=.762, p=.000)$ is significant predictor of Positive attitude toward the need for training in the field to lead to the digital school. This suggests that a higher level of positive perceptions of teachers regarding digital school is associated with higher level of -Positive attitude toward the need for training in the field to lead to the digital school. For every one unit increase in perception of teachers for regarding digital school score, there is a corresponding increase of .762 in score of positive attitude toward the need for training in the field to lead to the digital school. The linear regression equation is: $\hat{Y}=3.72+.762$ Positive perceptions of teachers regarding digital school. Table 5 summarizes this regression model.

Table 5. The general linear regression model for prediction of the need for training in the field to lead to the positive perceptions of teachers regarding digital school.

Coefficients $^{3}$

\begin{tabular}{|c|c|c|c|c|c|c|}
\hline & \multirow{2}{*}{ Model } & \multicolumn{2}{|c|}{$\begin{array}{l}\text { Unstandardized } \\
\text { Coefficients }\end{array}$} & \multirow{2}{*}{$\begin{array}{c}\text { Standardized } \\
\text { Coefficients } \\
\text { Beta }\end{array}$} & \multirow[t]{2}{*}{$\mathrm{t}$} & \multirow[t]{2}{*}{ Sig. } \\
\hline & & $\mathrm{B}$ & Std. Error & & & \\
\hline \multirow[b]{2}{*}{1} & (Constant) & 3.726 & 0.401 & & 9.291 & 0.426 \\
\hline & Positive perceptions of teachers regarding digital school & 0.762 & 0.039 & 0.713 & 19.408 & 0.000 \\
\hline
\end{tabular}

a. Positive attitude toward the need for training in the field to lead to the digital school 


\section{Conclusions}

In summary, some results can be concluded at the end of this article. From the survey conducted in the population of teachers trained and certified in IT competences/skills near Albanian institutions of training and practice, is drawing a sample of 400 teachers through the stages sampling method. Out of 400 teachers of the sample, just 130 are men and the other 270 are women, or $32.5 \%$ are men and $67.5 \%$ are women. A Likert scale is used for the gathering of the data from the sample. Additionally, Cronbach's alpha was run in order to assess internal consistency and reliability for each of the scales used to collect the data. These scales have a good internal consistence, with a Cronbach alpha coefficient reported respectively, .81 and .72. A two tailed alpha level of .05 was set a priori and used for all statistical tests. To answer the question, if there exists or not the relationship between formative needs of the teachers and their attitude toward digital school, linear regression analysis is conducted. From this statistical analysis is revealed that there exists a positive relationship between the formative needs of teachers and their positive attitude toward digital school. The progressive improvement of the professional formation in the field improves positively the attitude of teachers toward digital school. For every one unit increase in perception of teachers for formative needs in the field score, there is a corresponding increase of .762 in score of positive perceptions of teachers regarding digital school.

From this result, it is concluded that policymakers and the state or private institutions/agencies should study better the formative offer to enable teachers to have access through the network resource II Cloud Computing. A successful training of teachers in Claud Computing leads to the successful application of the digital schools.

\section{References}

Albanian Government Progress Report 2012

Albanian National Strategy 2009-2014

Albanian National Curriculum 2003

Alessandrini G., Pignalberi C. (2012), Le sfide dell'educazione oggi. Nuovi habitat tecnologici, reti e comunità, Pensa Multimedia, Lecce. Bauman Z. (2006), Vita liquida, Laterza, Roma-Bari. .

Commissione Europea, (2010), Un'agenda digitale europea, Bruxelles.

Cohen, Manion \& Morison (1970), Research Methods in Education, Routledge

Francesco Avvisati, Sara Hennessy,Robert B. Kozma and Stéphan Vincent-Lancrin (2013) Review of the Italian Strategy for Digital Schools

Ferrari A., Zanleone E. L. (2001), Cloud Computing. Aspettative, problemi, progetti e risultati di aziende passate al modello 'as a service', Milano, Franco Angeli

Giddens A. (1996), Le conseguenze della modernità, il Mulino, Bologna.

Granieri G. (2006), La società digitale, Laterza, Roma-Bari.

Julio Meneses and Josep Maria Momin'0: How Schools Contribute to Digital Inclusion in the Network Society, Cambridge Journal of Education,Vol. 41, No. 4, December 2011, 473-488

Lipari D. (2007), Metodi della formazione oltre l'aula: apprendere nelle comunità di pratica, Isfol, Roma, 12

Maragliano R. (2005), Pedagogie dell'e-learning, Laterza, Roma-Bari.

Mark Prensky Teaching Digital Natives, Corwin Press 2010, 27

Monitoring Report on Alter-text 2010, Albania

Reese G. (2010), Cloud Computing. Architettura, Infrastruttura, applicazioni, Tecniche Nuove, Milano. y Routledge

\section{Website}

http://www.bookinprogress.it/

http://www.ilsoftware.it/articoli.asp

www.apprendereinrete.it

http://www.majoranabrindisi.it/ 